\title{
CKD: A Guide to Higher Fiber Foods ${ }^{1}$
}

\author{
Wendy J. Dahl and Nancy J. Gal'
}

Living with chronic kidney disease (CKD) presents many challenges, and diet is one of them. People with CKD may find it difficult to consume enough fiber-rich foods while following the other diet recommendations for CKD. As kidney function declines, individuals with CKD may be recommended to limit foods high in phosphorus and potassium. As some of the restricted foods may also be high in fiber, these restrictions may result in a diet lower in fiber.

National guidelines for fiber intake by individuals with CKD are lacking (Krishnamurthy et al. 2012), but it is generally recommended that people with CKD consume a diet higher in fiber. The fiber recommendations for CKD may be similar to what is recommended for healthy individuals: 21 to $25 \mathrm{~g}$ of fiber per day for women and 30 to 38 $\mathrm{g}$ of fiber for men depending on age (Trumbo et al. 2002). On average, people with CKD consume only about $15 \mathrm{~g}$ of fiber per day (Evenepoel and Meijers 2012). However, it is possible to follow the dietary restrictions for the later stages of CKD and still consume the recommended amount of fiber. This guide will discuss the health benefits of fiber and provide some examples of fiber-rich foods that may be good choices for people with CKD.

\section{Health Benefits of Fiber and CKD}

Fiber is naturally found in all plant foods, including fruits, vegetables, grains, nuts, seeds, and legumes. Fiber, when isolated from plants, can also be added to foods to create higher fiber foods. Consuming adequate fiber maintains a healthy digestive tract and lowers the risk of developing heart disease, type 2 diabetes, and other chronic diseases (Dahl and Stewart 2015). Higher fiber intakes are also recommended for the management of many chronic diseases, as fiber helps lower cholesterol and control blood sugar. Fiber may also be beneficial for the management of blood pressure (Aleixandre and Miguel 2016).

Consuming the recommended amount of fiber may have a number of benefits for people with CKD. Higher fiber intakes are linked to improved survival (Krishnamurthy et al. 2012), as are healthy dietary patterns that provide fiber from fruit, vegetables, legumes, and whole grains (Kelly et al. 2016).

Adequate fiber, particularly insoluble fiber, may be helpful in promoting laxation and preventing constipation in people with CKD (Salmean, Zello, and Dahl 2013). Diabetes is a leading cause of kidney failure. Consuming foods that contain fiber may help with blood glucose control (Post et al. 2012) which might delay the progression of the disease (Shurraw et al. 2011; Lee et al. 2013). The higher risk of cardiovascular disease that comes with CKD may be lessened with fiber by lowering cholesterol and inflammation (Dahl et al. 2016).

\section{Increasing Fiber with CKD}

In the early stages of $\mathrm{CKD}$, when there are usually no restrictions of potassium, it is recommended to consume a variety of foods providing fiber, such as whole grains, legumes, fruits, vegetables, nuts, and seeds.

1. This document is FSHN18-2, one of a series of the Food Science and Human Nutrition Department, UF/IFAS Extension. Original publication date January 2018. Visit the EDIS website at http://edis.ifas.ufl.edu.

2. Wendy J. Dahl, associate professor, Department of Food Science and Human Nutrition, UF/IFAS Extension, Gainesville, FL 32611 ; and Nancy J. Gal, Extension agent IV, Food and Consumer Sciences, UF/IFAS Extension, Ocala, FL 34470.

The Institute of Food and Agricultural Sciences (IFAS) is an Equal Opportunity Institution authorized to provide research, educational information and other services

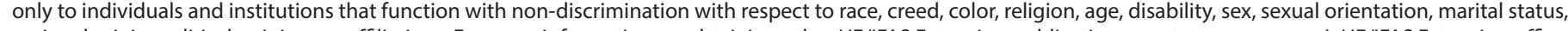

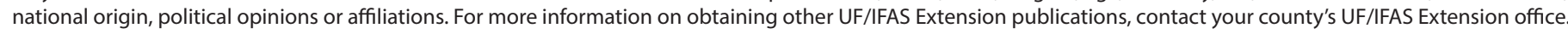
U.S. Department of Agriculture, UF/IFAS Extension Service, University of Florida, IFAS, Florida A \& M University Cooperative Extension Program, and Boards of County Commissioners Cooperating. Nick T. Place, dean for UF/IFAS Extension. 
Many whole-grain foods and legumes are good sources of fiber, but have traditionally been limited in the CKD diet due to their phosphorus content. Although plant foods such as whole grains contain a significant amount of phosphorus, they are healthful food choices for those with CKD. This is because only a fraction of the phosphorus from whole grains is absorbed into the body (Williams, Ronco, and Kotanko 2013). Table 1 provides a list of whole grain foods.

Foods with added fiber can help to achieve fiber recommendations and may have beneficial health effects (Chiavaroli et al. 2014). Table 2 gives some examples of grain-based foods with added fiber. For more information on foods with added fiber, see http://edis.ifas.ufl.edu/pdffiles/FS/FS23500. pdf.

Fruits and vegetables are also important sources of fiber. Legumes, such as beans, peas, and lentils, are especially high in fiber, providing as much as $8 \mathrm{~g}$ of fiber per $1 / 2$ cup serving. However, some people with CKD may need to restrict legumes and some fruits and vegetables due to their potassium content. For those with people with CKD who have been advised to restrict potassium, there are lower potassium fruits and vegetables to choose from. Examples are listed in Table 3.

It is recommended that people with CKD consult with a registered dietitian nutritionist (RDN), preferably one who specializes in kidney disease, before changing their diet. A dietitian can help with choosing optimum food sources of fiber for each stage of CKD.

\section{Resources}

For more information about the phosphorus contents of select foods, visit the United States Department of Agriculture's website at http://www.nal.usda.gov/fnic/foodcomp/ Data/SR17/wtrank/sr17a305.pdf. This site provides an extensive index of all types of foods and their specific contents of phosphorous.

\section{References}

Aleixandre, A., and M. Miguel. 2016. "Dietary fiber and blood pressure control." Food Funct 7(4):1864-71. doi: 10.1039/c5fo00950b.

Chiavaroli, L., A. Mirrahimi, J.L. Sievenpiper, D.J. Jenkins, and P.B. Darling. 2014. "Dietary fiber effects in chronic kidney disease: a systematic review and meta-analysis of controlled feeding trials." Eur J Clin Nutr. doi: 10.1038/ ejcn.2014.237.
Dahl, W. J., and M.L. Stewart. 2015. "Position of the Academy of Nutrition and Dietetics: Health Implications of Dietary Fiber." J Acad Nutr Diet 115(11):1861-70. doi: 10.1016/j.jand.2015.09.003.

Dahl, W.J., N.C. Agro, A.M. Eliasson, K.L. Mialki, J.D. Olivera, C.T. Rusch, and C.N. Young. 2016. "Health benefits of fiber fermentation." Journal of the American College of Nutrition.

Evenepoel, P., and B.K. Meijers. 2012. "Dietary fiber and protein: nutritional therapy in chronic kidney disease and beyond." Kidney Int 81(3):227-9. doi: 10.1038/ki.2011.394.

Kelly, J.T., S.C. Palmer, S.N. Wai, M. Ruospo, J.J. Carrero, K.L. Campbell, and G.F. Strippoli. 2016. "Healthy Dietary Patterns and Risk of Mortality and ESRD in CKD: A Meta-Analysis of Cohort Studies." Clin J Am Soc Nephrol. doi: 10.2215/cjn.06190616.

Krishnamurthy, V.M., G. Wei, B.C. Baird, M. Murtaugh, M.B. Chonchol, K.L. Raphael, T. Greene, and S. Beddhu. 2012. "High dietary fiber intake is associated with decreased inflammation and all-cause mortality in patients with chronic kidney disease." Kidney Int 81(3):300-6. doi: 10.1038/ki.2011.355.

Lee C.L., T.C. Li, S.Y. Lin, J.S. Wang, I.T. Lee, L.N. Tseng, Y.M. Song, S.F. Tsai, and W.H. Sheu. 2013. "Dynamic and dual effects of glycated hemoglobin on estimated glomerular filtration rate in type 2 diabetic outpatients." Am J Nephrol. 38:19-26.

Post, R.E., A.G. Mainous, D.E. King, and K.N. Simpson. 2012. "Dietary fiber for the treatment of type 2 diabetes mellitus: a meta-analysis." J Am Board Fam Med 25(1):1623. doi: 10.3122/jabfm.2012.01.110148.

Salmean, Y.A., G.A. Zello, and W.J. Dahl. 2013. "Foods with added fiber improve stool frequency in individuals with chronic kidney disease with no impact on appetite or overall quality of life." BMC Res Notes 6:510. doi: 10.1186/1756-0500-6-510.

Shurraw, S., B. Hemmelgarn, M. Lin, S.R. Majumdar, S. Klarenbach, B. Manns, A. Bello, M. James, T.C. Turin, and M. Tonelli. 2011. "Association between glycemic control and adverse outcomes in people with diabetes mellitus and chronic kidney disease: a population-based cohort study." Arch Intern Med. 171:1920-1927. 
Trumbo, P., S. Schlicker, A.A. Yates, and M. Poos. 2002. "Dietary reference intakes for energy, carbohydrate, fiber, fat, fatty acids, cholesterol, protein and amino acids." J Am Diet Assoc. 102(11):1621-30. 
Table 1. Fiber and nutrient contents of some whole-grain foods. (USDA 2017)

\begin{tabular}{|c|c|c|c|c|c|}
\hline Cereals & Serving Size & Fiber $(\mathbf{g})$ & Potassium (mg) & Phosphorus (mg) & Sodium (mg) \\
\hline Health Valley Fiber 7 Flakes & $3 / 4$ cup & 4.4 & 149 & 101 & 62 \\
\hline Health Valley Oat Bran Flakes & $3 / 4$ cup & 3.0 & 128 & 129 & 142 \\
\hline Kashi 7 Whole Grain Flakes & $3 / 4$ cup & 4.4 & 92 & 65 & 109 \\
\hline Kellogg's Mueslix & $3 / 4$ cup & 4.7 & 199 & 139 & 147 \\
\hline Kellogg's All-bran Bran Buds & $1 / 4$ cup & 9.6 & 183 & 113 & 154 \\
\hline Kellogg's Miniwheats unfrosted & 15 biscuits & 3.8 & 127 & 129 & 1 \\
\hline Post Shredded Wheat n'Bran & $3 / 4$ cup & 5.2 & 138 & 148 & 0 \\
\hline Post ${ }^{\oplus}$ Bran Flakes & $3 / 4$ cup & 5.5 & 160 & 135 & 162 \\
\hline Post $^{\oplus}$ Grape Nuts & $1 / 4$ cup & 3.8 & 116 & 134 & 135 \\
\hline Post $^{\oplus}$ Shredded Wheat n'Bran & $3 / 4$ cup & 5.2 & 138 & 148 & 0 \\
\hline Uncle Sam ${ }^{\oplus}$ Cereal & $3 / 4$ cup & 11.2 & 245 & 206 & 113 \\
\hline Weetabix Whole Grain & $3 / 4$ cup & 4.9 & 183 & 74 & 159 \\
\hline Breads & Serving Size* & Fiber (g) & Potassium (mg) & Phosphorus (mg) & Sodium (mg) \\
\hline Cracked wheat & 1 slice & 1.6 & 50 & 43 & 153 \\
\hline Oatmeal & 1 slice & 1.1 & 46 & 36 & 127 \\
\hline Oat bran & 1 slice & 1.3 & 42 & 40 & 100 \\
\hline Pumpernickel & 1 slice & 1.8 & 59 & 50 & 169 \\
\hline Rice bran & 1 slice & 1.4 & 61 & 50 & 76 \\
\hline Sprouted wheat & 1 slice & 1.5 & 55 & 49 & 133 \\
\hline White wheat & 1 slice & 2.6 & 36 & 29 & 134 \\
\hline Whole wheat & 1 slice & 1.7 & 72 & 60 & 128 \\
\hline Crackers & Serving Size & Fiber $(\mathbf{g})$ & Potassium (mg) & Phosphorus (mg) & Sodium (mg) \\
\hline Triscuit $^{\circledast}$ Crackers Hint of Salt & 6 crackers & 3 & $120 \mathrm{mg}$ & $10 \%$ & $50 \mathrm{mg}$ \\
\hline Ryvita $^{\circledR}$ Original Crispbread & 2 slices & 3 & N/A & $\mathrm{N} / \mathrm{A}$ & $60 \mathrm{~g}$ \\
\hline
\end{tabular}

Table 2. Fiber and nutrient content of some grain-based foods with added fiber. (USDA 2017)

\begin{tabular}{|c|c|c|c|c|c|}
\hline Grain-based foods with added fiber & $\begin{array}{l}\text { Serving } \\
\text { Size }\end{array}$ & Fiber $(\mathbf{g})$ & $\begin{array}{l}\text { Potassium } \\
\text { (mg) }\end{array}$ & Phosphorus (mg) & $\begin{array}{l}\text { Sodium } \\
\text { (mg) }\end{array}$ \\
\hline Arnold Sandwich Thins ${ }^{\ominus}$ & 1 roll $(43 \mathrm{~g})$ & $5 \mathrm{~g}$ & $\mathrm{~N} / \mathrm{A}$ & $\mathrm{N} / \mathrm{A}$ & $170 \mathrm{mg}$ \\
\hline Barilla Pasta Added Fiber & $2 \mathrm{oz}$ & $6 \mathrm{~g}$ & N/A & N/A & $0 \mathrm{mg}$ \\
\hline Carb Balance Flour Tortillas & $1(42 \mathrm{~g})$ & $13 \mathrm{~g}$ & $\mathrm{~N} / \mathrm{A}$ & N/A & $280 \mathrm{mg}$ \\
\hline FiberOne ${ }^{\circledast}$ with Bran cereal & $1 / 2$ cup & $13.9 \mathrm{~g}$ & $112 \mathrm{mg}$ & $60 \mathrm{mg}$ & $107 \mathrm{mg}$ \\
\hline FiberOne ${ }^{\circledast}$ Italian Bread & 1 slice & $3 \mathrm{~g}$ & N/A & N/A & $130 \mathrm{mg}$ \\
\hline High Fiber Egg Noodles & $2 \mathrm{oz}$ & $7 \mathrm{~g}$ & N/A & N/A & $10 \mathrm{mg}$ \\
\hline MM Mania Fiber Biscotti & $1 \mathrm{oz}$ & $6 \mathrm{~g}$ & N/A & N/A & $70 \mathrm{mg}$ \\
\hline MM Mania Fiber Breadsticks & $1 \mathrm{oz}$ & $11 \mathrm{~g}$ & N/A & N/A & $140 \mathrm{mg}$ \\
\hline Quaker Instant Oatmeal High Fiber & $1 \mathrm{pkt}$ & $10 \mathrm{~g}$ & $115 \mathrm{mg}$ & $138 \mathrm{mg}$ & $213 \mathrm{mg}$ \\
\hline Wheatabix Crispy Flakes and Fiber Cereal & 1 cup & $4.4 \mathrm{~g}$ & $124 \mathrm{mg}$ & N/A & $128 \mathrm{mg}$ \\
\hline
\end{tabular}


Table 3. Fiber and nutrient contents of some lower potassium vegetables and fruits.* (USDA 2017)

\begin{tabular}{|c|c|c|c|c|c|}
\hline Vegetables & Serving Size & Fiber (g) & Potassium (mg) & Phosphorus (mg) & $\begin{array}{c}\text { Sodium } \\
\text { (mg) }\end{array}$ \\
\hline Broccoli (raw, chopped) & $1 / 2$ cup & 1.2 & 144 & 30 & 15 \\
\hline Cabbage (raw, chopped) & $1 / 2$ cup & 1.1 & 76 & 12 & 8 \\
\hline Carrot (raw) & 1 small & 1.4 & 160 & 18 & 34 \\
\hline Cauliflower (raw, chopped) & $1 / 2$ cup & 1.1 & 160 & 24 & 16 \\
\hline Celery (raw, stalk) & 1 medium & 0.6 & 104 & 10 & 32 \\
\hline Corn (kernels, cooked) & $1 / 2$ cup & 2.1 & 198 & 72 & 2 \\
\hline Cucumber (raw, peeled, chopped,) & $1 / 2$ cup & 0.5 & 90 & 14 & 1 \\
\hline Eggplant (peeled, cubed, cooked) & $1 / 2$ cup & 1.2 & 61 & 7 & 0 \\
\hline Green beans (cooked) & $1 / 2$ cup & 2.0 & 91 & 18 & 1 \\
\hline Green Pepper (chopped, raw) & $1 / 2$ cup & 1.3 & 130 & 15 & 2 \\
\hline Radish (raw, sliced) & $1 / 2$ cup & 0.9 & 135 & 12 & 23 \\
\hline Zucchini (raw, with peel, chopped) & $1 / 2$ cup & 0.6 & 162 & 24 & 5 \\
\hline Fruit & Serving Size & Fiber (g) & Potassium (mg) & Phosphorus (mg) & $\begin{array}{c}\text { Sodium } \\
\text { (mg) }\end{array}$ \\
\hline Apple & 1 small & 3.6 & 159 & 16 & 1 \\
\hline Blueberries & $1 / 2$ cup & 1.8 & 57 & 9 & 1 \\
\hline Blackberries & $1 / 2$ cup & 3.8 & 117 & 16 & 1 \\
\hline Cherries (sweet, with pits) & $1 / 2$ cup & 1.4 & 153 & 14 & 0 \\
\hline Grapefruit (raw, pink and red) & $1 / 2$ whole & 1.4 & 156 & 11 & 0 \\
\hline Grapes (red or green) & 15 & 0.7 & 140 & 15 & 1 \\
\hline Pear with skin & 1 small & 4.6 & 172 & 18 & 1 \\
\hline Pineapple (chunks) & $1 / 2$ cup & 1.2 & 90 & 7 & 1 \\
\hline Plum with skin & 1 medium & 0.9 & 104 & 11 & 0 \\
\hline Raspberries & $1 / 2$ cup & 4.0 & 93 & 18 & 1 \\
\hline Tangerine & 1 small & 1.4 & 126 & 15 & 2 \\
\hline Strawberries (whole) & $1 / 2$ cup & 1.4 & 110 & 17 & 1 \\
\hline
\end{tabular}

